\title{
Minining
}

http://dx.doi.org/10.1590/0370-44672018720016

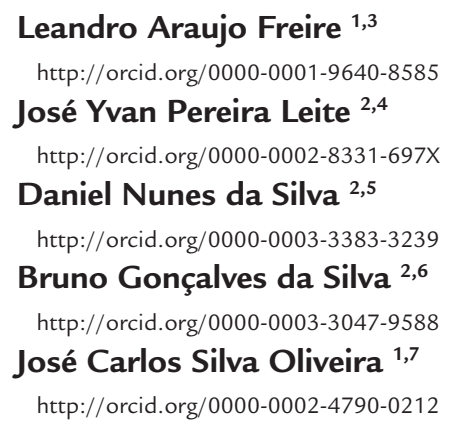

${ }^{1}$ Universidade Federal de Pernambuco - UFPE, Departamento de Engenharia de Minas, Recife - Pernambuco - Brasil.

${ }^{2}$ Instituto Federal de Educação Ciência e Tecnologia do Rio Grande do Norte, Natal - Rio Grande do Norte - Brasil.

E-mails: ${ }^{3}$ leandro.araujof@hotmail.com, 4jyp.leite@ifrn.edu.br, ${ }^{5}$ dnielnunes@gmail.com, 6brunoGonsalves49@gmail.com, 7josecarlosdasoliveiras@gmail.com

\section{Behavior of the chromite tailings in a centrifugal concentrator (FALCON)}

\begin{abstract}
The application of the centrifugal concentration gains importance in the world scenario, considering the low environmental impact and the concentration of fine particles. Literature does not present articles using centrifugal concentration (Falcon) for chromite. The material used in the tests is the tailings from a Northeastern Brazil concentration plant, which was homogenized in the laboratory. In the process assays, the number of $\mathrm{G}(25-300 \mathrm{G})$ and the fluidization water pressure $(20-100 \mathrm{kPa})$ were optimized. The initial tests used a wide range of particle size of $1 \mathrm{~kg}$ mass, with the "best results" being for 50 and $100 \mathrm{G}$ at a pressure of 60 and $80 \mathrm{kPa}$, respectively, where a metallurgical recovery of $25 \%$ and grade close to $20 \%$ of $\mathrm{Cr}_{2} \mathrm{O}_{3}$ were obtained. The amount of mass showed to be a significant variable in the process, being $250 \mathrm{~g}$ the ideal for the material used, which obtained considerable recoveries, even though the grade is still low. These results led to a cut at $250 \mu \mathrm{m}$, considering that the liberation of the chromite is of the order of $77 \%$. The best result was with $150 \mathrm{G}$ and fluidization water pressure of $60 \mathrm{kPa}$ for a metallurgical recovery of $72 \%$ and a grade of $28 \% \mathrm{Cr}_{2} \mathrm{O}_{3}$.
\end{abstract}

keywords: centrifugal concentrator; Falcon; chromite; tailings.

\section{Introduction}

Chromium minerals are found on Earth under the form of oxides and silicates. However, chromite is the only chromium mineral with an economically viable production, which gives it an outstanding position in the mineral industry. Its theoretical composition is $68 \% \mathrm{Cr}_{2} \mathrm{O}_{3}$ and $32 \% \mathrm{FeO}$ : however, these grades are never found in nature, due to the existence of contaminations.

Chromite is one of the most important industrial minerals: It is used in the metallurgical (main consumption), refractory, chemical and foundry industries. It was first used as a pigment in the late eighteenth century. In the early nineteenth century, it was discovered that this mineral provided stainless properties to the alloy steels (SAMPAIO, ANDRADE AND
PAIVA, 2008).

Centrifugal concentrators are machines that emerged in the 80's and exert a high centrifugal force, which can be used for a retraction of tailings of heavy minerals such as chromite, gold, scheelite, among others, making better use of the mineral concentrate. They have relatively low operating and equipment costs, as stated by Sampaio and Tavares (2005). Falcon applications can be found in literature. Initially, centrifugal concentrator application was restricted to the concentration of gold. Leite and Freitas (2001) carried out experiments with this ore in a region of Pedra Lavrada-PB, reaching concentrations around 82\%. Also, Lins et al. (1992) verified that Falcon was able to recover fine particles of gold $(-74 \mu \mathrm{m})$ in the order of
$44 \%$ in 30 minutes of operation in sulfide ore $(17 \%$ pyrite and $2 \%$ chalcopyrite). Applications related to coal were studied by Honaker, Wang and Ho (1996): the researchers efficiently reduced the ash and sulfur grade in the coal fines, with the maximum separation achieved in the particle size range between $210 \times 37 \mu \mathrm{m}$.

More recently, studies over the subject of gravity separation tailings have been developed. Fernandes (2011) performed a pre-concentration of scheelite using a Falcon SB-40 for posterior acid leaching. Leite and Souza (2010) studied the behavior of kaolin reject, and the results showed that the concentrator operated by classifying the particles with greater inertia, while the fine kaolin particles behaved as a fluid. This process led to recoveries in the order 
of $90 \%$ of kaolin, showing that its application may be an alternative to increase the recovery of kaolin in the region. Sen (2016) indicated that fluidization water flow rate

\section{Materials and methods}

The chromite tailings were sent to the Rio Grande do Norte Mineral Technology Laboratory (IFRN), Campus Natal, in seven bags, with an average of $22 \mathrm{~kg}$

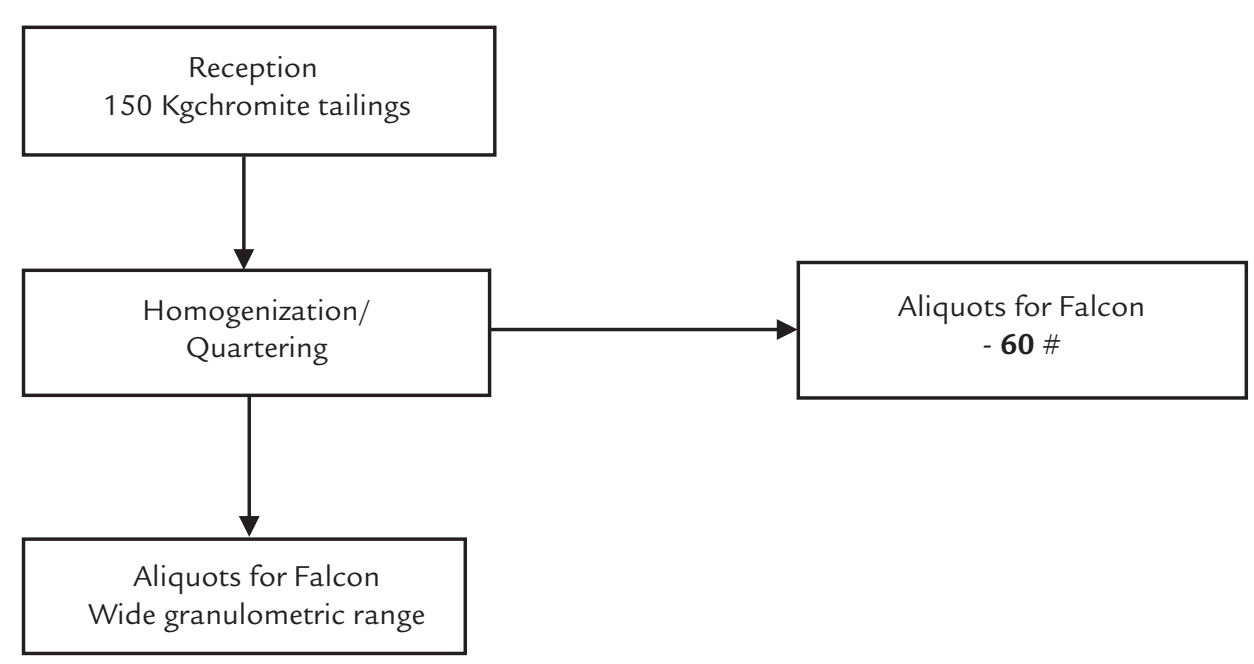

was the independent variable affecting both grade and recovery of the chromite concentrate in Knelson.

The objective of this study is to per bag. The material was homogenized using prismatic cells. The aliquots for the centrifugal concentration assays were prepared by a Jones splitter. The centrifugal verify the application of the centrifugal concentration in metallurgical recovery of the plant and processing waste, so that a reuse of the chromite can be planned.

concentrator used was a Falcon SB-40 model. The methodology of the study is expressed in Figure 1. The material retained in Falcon's rings was called concentrate.

Figure 1

Methodology flowchart

for the lab process steps.

\section{Results and discussion}

The samples of chromite tailing used in this work present $8.41 \%$ of $\mathrm{Cr}_{2} \mathrm{O}_{3}$. This material is composed mainly chromite (specific gravity:

$4.50-5.09$ ), serpentine (specific gravity:2.53-2.65) and talc (specific gravity: $2.7-2.8)$. It has been found that $48 \%$ of the tailings particles are

\subsection{Centrifugal concentration in a wide granulometric range}

The metallurgical recovery for a function of the fluidization water $\mathrm{Cr}_{2} \mathrm{O}_{3}$ from the chromite tailing as pressure for the centrifugal accelera-

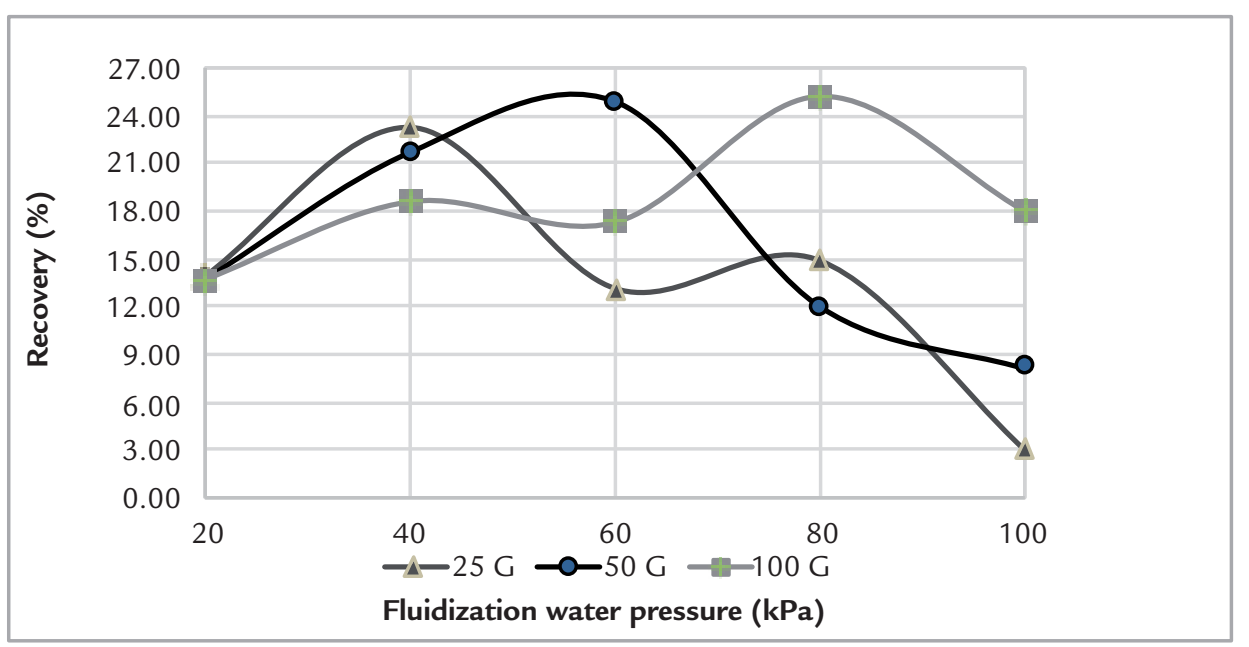

The best metallurgical recoveries were 23.27, 24.89 and $25.22 \% \mathrm{Cr}_{2} \mathrm{O}_{3}$, which were reached for centrifugal accelerations 25, 50 and $100 \mathrm{G}$ and fluidization water pressures of 40, 60 and $80 \mathrm{kPa}$, respectively. The results indicate that higher fluidization pressures require higher centrifugal accelerations. In the centrifugal accelerations 25, 50 and $100 \mathrm{G}$, the metallurgical recovery decreased from 40, 60 and $80 \mathrm{kPa}$, respectively, considering that the chromite less than $300 \mu \mathrm{m}$. It was observed that $80 \%$ of the chromite is liberated from $150 \mu \mathrm{m}$ (FREIRE et al., 2017).

tions of 25, 50 and $100 \mathrm{G}$ is shown in Figure 2.
Figure 2

Recovery $\left(\mathrm{Cr}_{2} \mathrm{O}_{3}\right)$ as a functi on of the fluidization water pressure.

particles were possibly ejected from the retaining rings.

Figure 3 shows the metallurgical recovery of $\mathrm{Cr}_{2} \mathrm{O}_{3}$ in the chromite tailings as a function of the fluidization water pressure at two levels of acceleration (150 and $200 \mathrm{G}$ ). 
Figure 3

Recovery and grade as a function of the fluidization water pressure (150 and $200 \mathrm{G}$ ).

The grade of the chromite concentrate reached $15.40 \% \mathrm{Cr}_{2} \mathrm{O}_{3}$ at a fluidization water pressure of $100 \mathrm{kPa}$ and centrifugal acceleration of $150 \mathrm{G}$. At $200 \mathrm{G}$, the grade of the concentrates was below $11 \% \mathrm{Cr}_{2} \mathrm{O}_{3}$ at all levels of fluidization water pressure, resulting in low values of metallurgical recovery.

\subsection{Centrifugal concentration under}

Figure 4 shows the $\mathrm{Cr}_{2} \mathrm{O}_{3}$ metallurgical recovery in the chromite concentrate obtained as a function of the feed mass, for the centrifugal acceleration levels of 50, 75 and $100 \mathrm{G}$ and fluidization water pres-

Figure 4

Recovery and grade as a function of the initial feed, in 60, 70 and $80 \mathrm{kPa}$ pressures and 50, 75 e $100 \mathrm{G}$ accelerations.

It can be seen from Figure 4 that recoveries tend to decrease with higher amounts of feed mass. This can be explained by filling the available volume of the rings to concentrate the minerals.

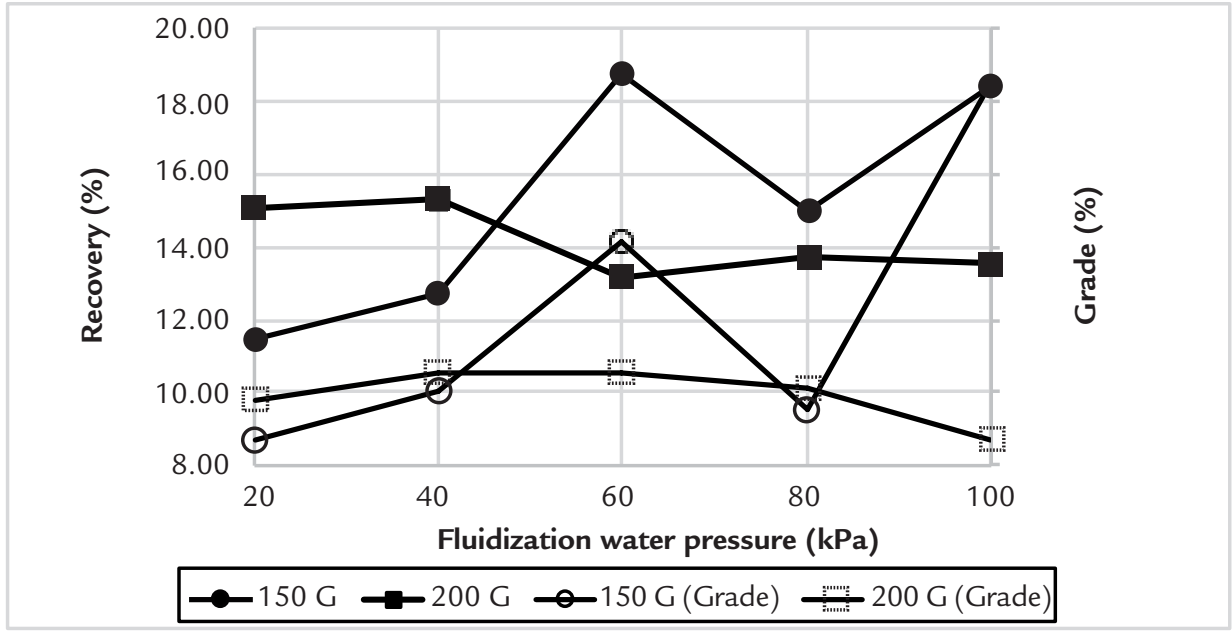

The results indicate that high centrifugal accelerations, such as $200 \mathrm{G}$, caused the contamination on the chromite's concentrate with large and light mineral particles. Because of the inertia of the particles, the bigger particles fill the retention rings, obstructing the access of the chromite's concentrate. Another aspect also observed is that in the wide range, there are mixed particles that may interfere with the concentrate grade.

In order to evaluate the grade and the metallurgical recovery, with other parameters, the influence of the feed in the process of centrifugal concentration using the Falcon SB-40 was examined.

\section{variable feed in a wide granulometric range}

sures of 60,70 and $80 \mathrm{kPa}$, respectively.

The acceleration for these tests was chosen due to the fact that 50 and $100 \mathrm{G}$ presented the best results in the tailings with a wide granulometric range, as seen in Figure 3. The acceleration of $75 \mathrm{G}$ was chosen for being between the other two values (50 and $100 \mathrm{G}$ ), which at the beginning of the experiments presented the best results.

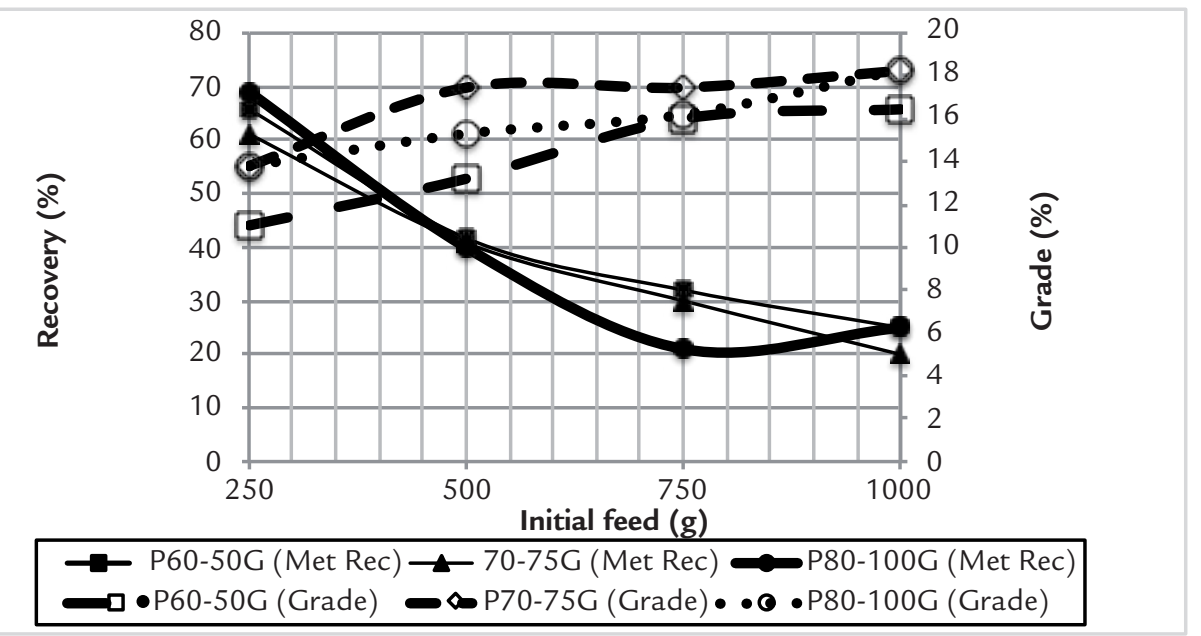

The available volume of Falcon SB40 retention rings is only $40.51 \mathrm{~cm}^{3}$. Considering that the bulk density of the chromite concentrate is 2.84 , the rings are completely filled in $115 \mathrm{~g}$. In other words, after filling the rings, the rest of the material tends to be discarded. Recoveries of $69 \%$ (P80 - $100 \mathrm{G}$ ), 65.94\% (P60 - $50 \mathrm{G})$ and 61.07\% (P75 - 70G) were achieved with $250 \mathrm{~g}$.

\subsection{Centrifugal concentration of the chromite tailings in below 60 mesh fraction}

In this step, the effect of particle size on the chromite tailings process was investigated. For that, aliquots of the chromite tailings were used in the particle size less than $250 \mu \mathrm{m}$ (60 mesh), representing $37.34 \%$ weight and an average grade of $10.87 \% \mathrm{Cr}_{2} \mathrm{O}_{3}$, where $48.28 \%$ of $\mathrm{Cr}_{2} \mathrm{O}_{3}$ are distributed. In this fraction, the liberation degree of chromite is greater than $76 \%$.
Figure 5 shows the grade of the chromite concentrate, in the fraction below 60 mesh, by varying the feed and under the following conditions: (P60-50 G), (P70-75 G) and (P80-100 G). 


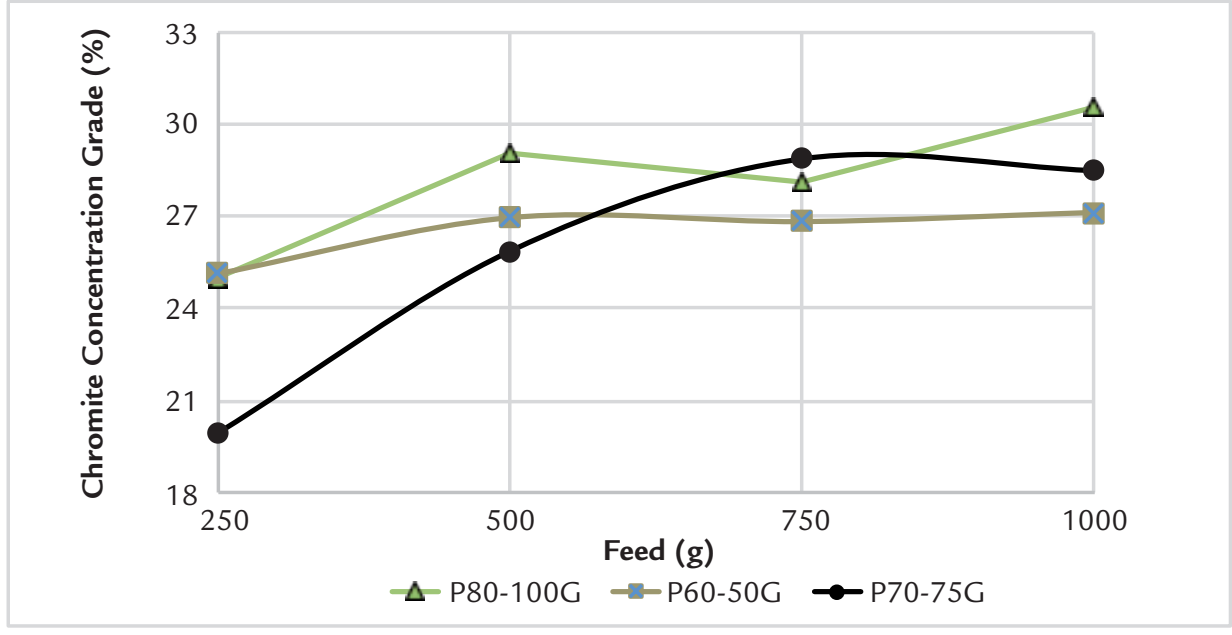

The results have shown that the chromite reject increased from $10.87 \%$

$\mathrm{Cr}_{2} \mathrm{O}_{3}$ to $27.14 \%$ (P60-50 G), $28.50 \%$ (P70-75 G) and 30.59\% (P80-100 G) for

\begin{tabular}{|c|c|c|c|}
\hline Centrifugal Acceleration & Pressure $(\mathrm{kPa})$ & Initial Feed (g) & Concentrate $(\mathrm{g})$ \\
\hline \multirow{4}{*}{$50 \mathrm{G}$} & \multirow{4}{*}{60} & 1000 & 18.28 \\
\hline & & 750 & 21.64 \\
\hline & & 500 & 17.98 \\
\hline & & 250 & 23.05 \\
\hline \multirow{4}{*}{75} & \multirow{4}{*}{70} & 1000 & 29.92 \\
\hline & & 750 & 27.66 \\
\hline & & 500 & 25.59 \\
\hline & & 250 & 21.42 \\
\hline \multirow{4}{*}{100} & \multirow{4}{*}{80} & 1000 & 22.85 \\
\hline & & 750 & 25.76 \\
\hline & & 500 & 30.49 \\
\hline & & 250 & 23.14 \\
\hline
\end{tabular}

From Table 1, it can be noticed that these pressure levels with these accelerations are inadequate due to the large amount of mass removed in the process, thus affecting the metallurgical recovery in all mass quantities tested.

Figure 6 shows the recovery val-

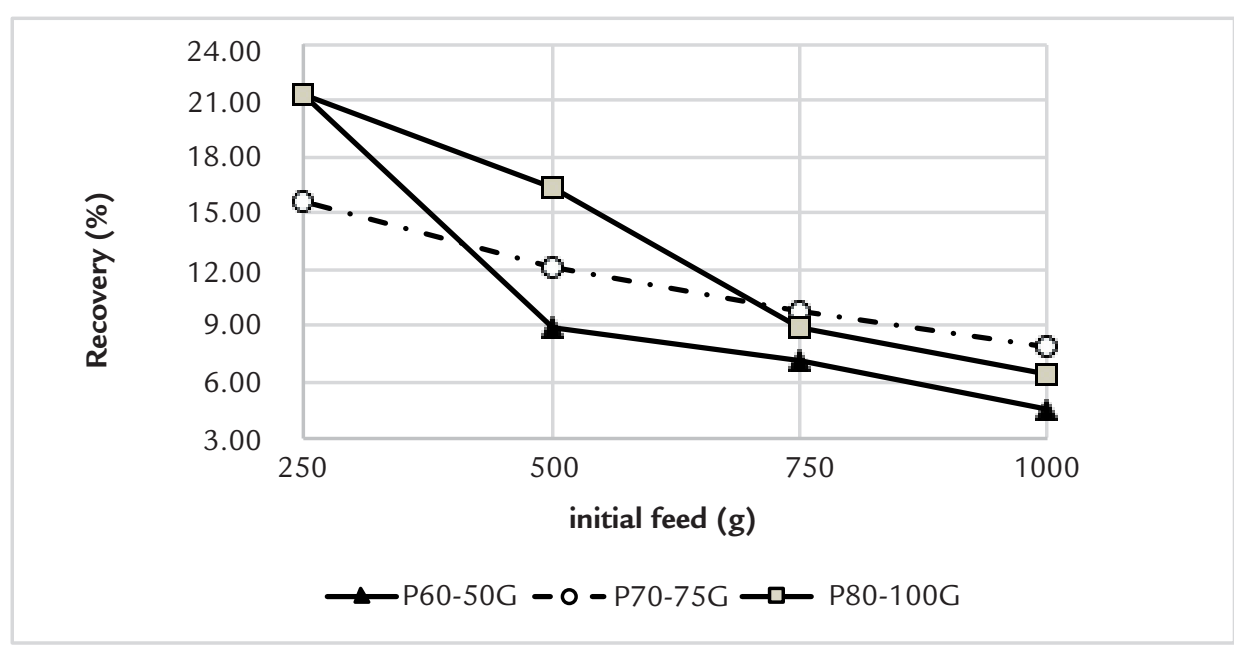

The medium to high pressures $(60-80 \mathrm{kPa})$ with relatively low accelerations (50-100 G), which showed the best results in the chromite tailings with a wide granulometric range (Figure 2), do not reach significant values with the material in below 60 mesh.

In order to raise the recovery
Figure 5

Chromite concentrate grade as a function of the feed mass in the below 60 mesh fraction.

feed of $1000 \mathrm{~g}$. Table 1 shows the mass reduction of the chromite concentrate.

Table 1

Mass decrease in chromite reject.

ues of $\mathrm{Cr}_{2} \mathrm{O}_{3}$ as a function of feed for the following conditions: (P60-50 G), (P70-75 G) and (P80-100G).

Figure 6

Recovery as a function of the feed mass in below 60 mesh fractions for 60,70 e $80 \mathrm{kPa}$ pressures and its rescpective accelerations (50, 75 e $100 \mathrm{G}$ ).

in the particle-size distribution and maintain a high grade, 250 grams of chromite concentrate were tested from low to intermediate accelera- 
tion level (100-150 G) with a low to medium pressure $(40-60 \mathrm{kPa})$.
Figure 7 shows the grade of the $100 \mathrm{G}$ and $150 \mathrm{G}$ tests.
Figure 7

Chromite concentrate grade as a function of the fluidization water pressure in the below 60 mesh reject (two acceleration levels).

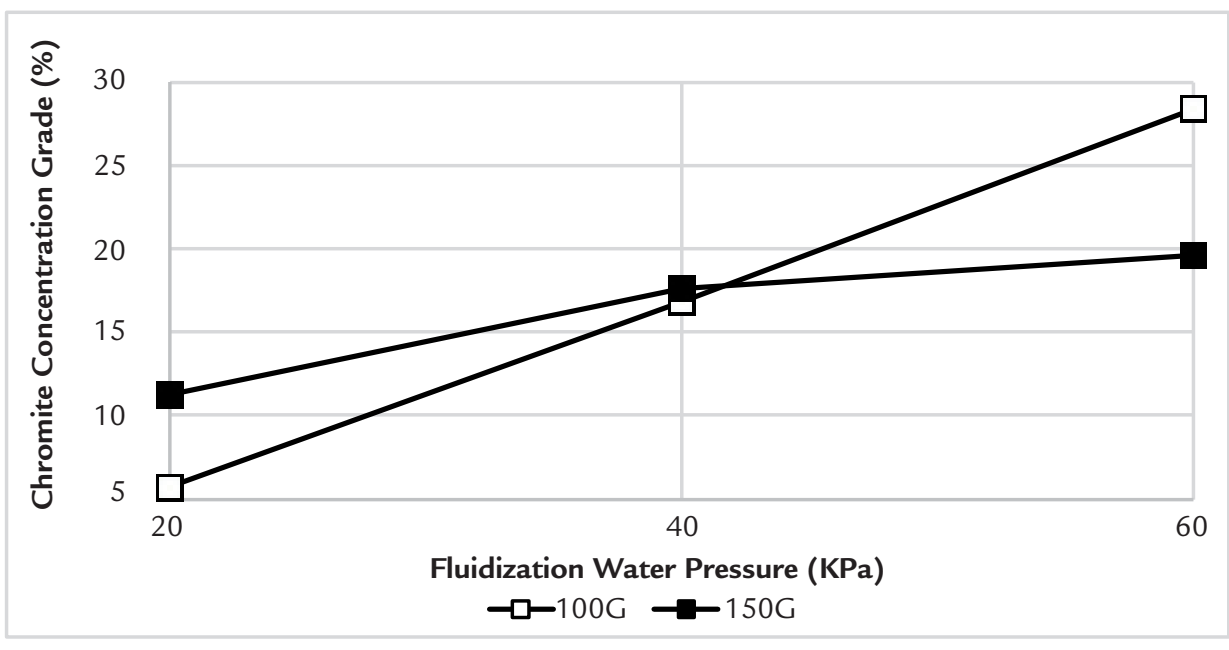

Figure 8 presents the results from the metallurgical recovery in the specified conditions.

Figure 8

Recovery as a function of the fluidization water pressure in a below 60 mesh reject (two acceleration levels).

\section{Conclusions}

When studying the behavior of the chromite tailings in a Falcon SB-40 centrifugal concentrator, it was verified that:

- The coarser material presents better results at smaller accelerations (50 a $100 \mathrm{G}$ ) with medium to high pressures (60 to $80 \mathrm{kPa})$, while the finer material has a better performance at low to intermediate

\section{Acknowledgments}

The authors thank the Brazilian Innovation Agency (FINEP) and the Foundation for Research Support of the

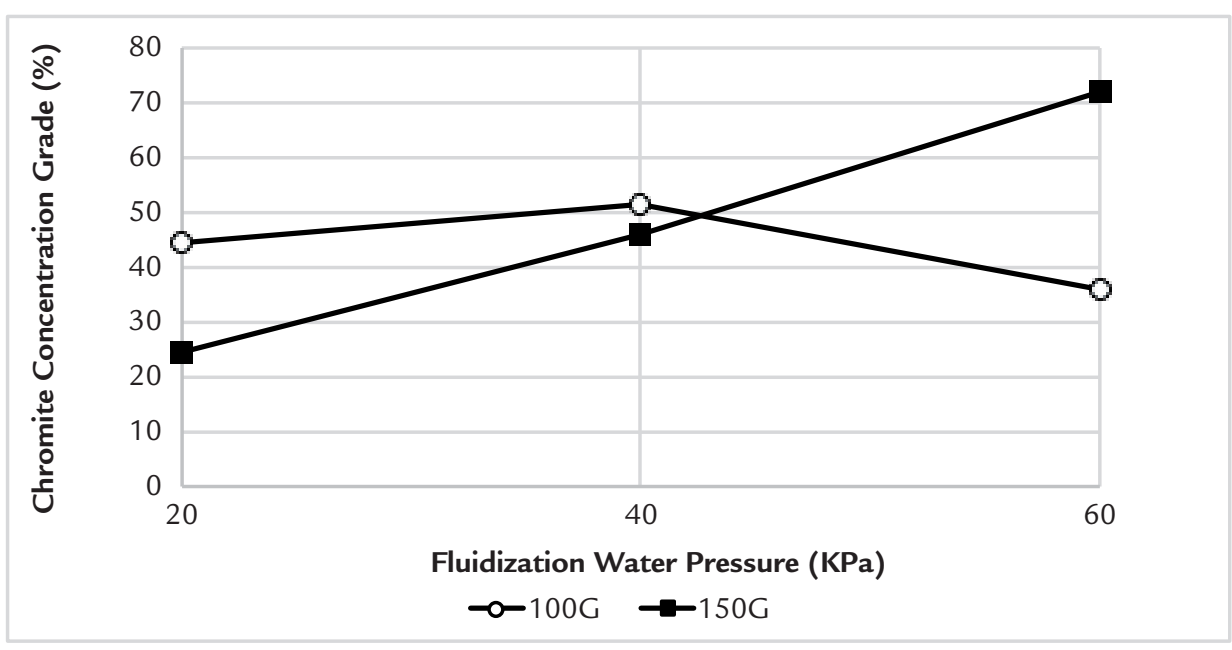

centrifugal acceleration (100-150 G) with low to medium pressures (40 to $60 \mathrm{kPa}$ );

- The equipment produces a large mass discard, serving better for a preconcentration than a proper concentration. Since $90 \%$ of the chromite is above 200 mesh, a good option is to preconcentrate the reject and then use it in traditional gravimetric equipment, such as an oscil- lating table or spirals;

- High centrifugal accelerations, such as $200 \mathrm{G}$, can trap the lighter and thicker particles, preventing better performance for the grade;

- The best results were $150 \mathrm{G}$ at 60 $\mathrm{kP}$ in below 60 mesh, where a recovery of $72 \%$ with a grade of $28.38 \%$ and $250 \mathrm{~g}$ of mass was achieved.
State of Rio Grande do Norte (FAPERN) for funding the project (Fortalecimento da Estrutura de Apoio à Pesquisa para o
Arranjo Produtivo Mineral do Rio Grande do Norte) and to CAPES for providing scholarships.

\section{References}

FERNANDES, B. R. B. Aproveitamento de finos de scheelita utilizando concentrador centrífugo e lixiviação ácida. Universidade Federal do Pernambuco, 2011. Xxf. (Dissertação de Mestrado em Engenharia Mineral).

FREIRE, L., OLIVEIRA, J. C. S., LEITE, J. Y. P., SILVA, D. N., SILVA, B. G. S., 
Caracterização tecnológica do rejeito de cromita. In: ENCONTRO NACIONAL DE TRATAMENTO DE MINÉRIOS E METALURGIA EXTRATIVA. Anais... Belém: IFPA, 2017. p. 521 - 528, 27, 2017.

HONAKER, R. Q., WANG, D. , HO, K. Application of Falcon concentrator for fine coal cleaning. Min Eng, Cornwall, v. 9, n. 11, p. 1143-1156, 1996.

LEITE, J. Y. P., FREITAS, F. Concentração de minério de ouro da fazenda Pedra Preta- PB utilizando concentrador centrífugo. In: ENCONTRO NACIONAL DE TRATAMENTO DE MINÉRIOS E METALURGIA EXTRATIVA, 18, 2001. Anais... Rio de janeiro: CETEM/MCT, 2001.p. 95 - 98.

LEITE, J. Y. P., SOUZA, L.L. Comportamento do rejeito de caulim em concentrador centrífugo. In: SIMPÓSIO DE MINERAIS INDUSTRIAIS DO NORDESTE, 2, 2010. Anais...Campina Grande: CETEM/UFPE, 2010. p. 83 - 90.

LINS, F. F., VEIGA, M. M., STEWART, J. A., PAPALIA, A., PAPALIA, R. Performance of a new centrifuge (falcon) in concentrating a gold ore from texada island, b.c., Canada. Min Eng, Cornwall, v. 5, n. 10 - 12, p. 1113 - 1121, 1992.

SAMPAIO, C. F., TAVARES, L. M. M. Beneficiamento gravimétrico: uma introdução aos processos de concentração mineral e reciclagem de materiais por densidade. Porto Alegre: UFGRS, 2005.

SAMPAIO, J. A., ANDRADE, M. C., PAIVA, P. R. P. Cromita. In: Luz, A., B., Lins, F. A. F. (Ed.). Rochas e minerais industriais: usos e especificações. (2.ed.). Rio de Janeiro: Cetem, 2008. p. 403 - 425.

SEN, G. A. Application of full factorial experimental design and response surface methodology for chromite beneficiation by knelson concentrator. Minerals, Basel, v. 6, n. 5, p. $1-11,2016$.

Received: 18 February 2018 - Accepted: 15 August 2018. 